\title{
A Report on the Special Executive Committee Meeting of the International Association for the History of Religions in Delphi
}

\author{
Don Wiebe \\ Faculty of Divinity, Trinity College in the University of Toronto, Toronto, \\ Ontario, Canada \\ dwiebe@trinity.utoronto.ca
}

\begin{abstract}
This essay is a report on the IAHR's Extended Executive Committee meeting in Delphi (13-15 September 2019), and a critical account of its decision, formulated prior to that meeting, to reject the IAHR's long-standing remit to support a scientific study of religion and religions. It is also a warning that insisting the IAHR be open to considering moral, social, political, spiritual or other cultural ideals will dismantle the only academic association committed to a scientific study of religions, transforming the IAHR into a weak, international version of the American Academy of Religion.
\end{abstract}

\section{Keywords}

IAHR - scientific study of religion - basic minimum presuppositions - epistemic commitments - cultural obligations distinction - R. J. Zwi Werblowsky - C. Jouco Bleeker

At its meeting in Ho Chi Minh City in July of 2017 the Executive Committee (EC) of the International Association for the History of Religions (IAHR) determined that "external and internal developments" in the field of the study of religion present serious challenges to the IAHR that required a response from the EC to ensure and strengthen its status as the preeminent international forum for the study of religion (Jensen to Wiebe, 14 January, 2018).

The Ec decided that the best way to deal with these challenges, as Professor Tim Jensen, President of the IAHR, spelled out in his letter of invitation to me, 
was to "arrange a special and extended IAHR EC meeting, dedicated to this purpose, with specially invited colleagues, dedicated to the IAHR" (Jensen to Wiebe, 14 January, 2018). This Extended Executive Committee (EEC) meeting was held in Delphi, Greece, from 13 to 15 September, 2019. I was formally invited to be a member of the EEC because I had directed two IAHR international congresses, and informally, it appears, "as a representative of the staunch scientific study of religion" (Fujiwara to Luther Martin, 3 January, 2019).

I appreciated the invitation to participate in this event because I agreed with the EC that concerted action needed to be taken if the IAHR were to survive as the only association in the field of religious studies dedicated to a scientific approach. However, I did not immediately accept the invitation since recent executive committees of the IAHR had given little attention to ensuring that the Association's practice would match its published scientific commitments. Recommended proposals for changes of name of the IAHR that included words like "science" or "scientific" had revealed over the past thirty years a neurotic fear of such words, despite the lip-service of successive executive committees to the IAHR's raison d'être as a scientific organization. And, finally, I was not satisfied that the current EC's criteria for membership on the EEC assured a fair representation of views about the history and nature of the IAHR.

Nevertheless, I finally accepted the invitation in January of 2019 because I was informed that the question of a change of name for the Association-a matter that has concerned me since 1987 - would be on the agenda; and, especially, because of the Ec's assurance, as affirmed in my letter of invitation, that "Despite whatever changes and challenges, the IAHR EC is fully devoted to the kind of academic, scientific study of religion staked out by Werblowsky et al. in Marburg 1960 and ... reiterated time and again by later leading IAHR figures" (Jensen to Wiebe, 14 January, 2018). ${ }^{1}$ Having decided to attend the meeting in Delphi, I submitted two "position papers" for discussion: the first paper"What's in a Name? For the IAH R, Just About Everything" — set out arguments

1 Raphael Judah Zwi Werblowsky (1924-2015) was an Israeli historian of religions long associated with the IAHR. He is widely known for his objection to what he saw as an invasion of personal, social, and cultural interests in the value of the study of religion in numerous papers presented at the 1960 IAHR international congress in Marburg. He insisted that the IAHR's responsibility was to guard and to cultivate the scientific study of religion and described that study in a set of "basic minimum presuppositions" which has since been adopted by successive Executive Committees as essential to the IAHR's identity. Werblowsky later served as Secretary General of the Association from 1975 to 1985 and then as a VicePresident of the Association (1985-1995). He was also for a time the editor-in-chief of Numen, the Association's journal. 
for the importance of the name itself for "branding" a future for the IAHR, and the second-"Globalization: Expansion and Demise of the IAHR" - provided reasons why an uncritical understanding of "globalization" as mere international expansion of the number of IAHR national member associations could ultimately undermine the IAHR's scientific raison d'être.

Unexpectedly, the EC invited Professor Ann Taves, Deputy Secretary General of the IAHR, to present a position paper in the opening session of the EEC (distributed along with my papers, prior to the Delphi meeting) that challenged "the kind of academic, scientific study of religion staked out by Werblowsky" and the defence of Werblowsky's position in my papers. Taves's presentation made sense of the warning I had already received from a member of the EC that a change of name was in the offing but it would not include "science" or "scientific study" that I had put forward in my position paper. Nevertheless, I attended the EEC meeting in Delphi despite this turn of events because I thought it important for the IAHR to retain its solid institutional (political) footing for its historical mandate for a scientific study of religion.

Reporting on the results of the EEC meeting in Delphi will not make much sense without at least a minimal understanding of the emergence and history of the development of the IAHR. Such an understanding was expected of every member of the EEC who had been urged to acquaint themselves with that information as presented in the volume of essays edited by Tim Jensen and Armin W. Geertz: NVMEN The Academic Study of Religion, and the IAHR: Past, Present, and Prospects (2016).

The IAHR is the oldest and most renowned organization committed to sustaining a scientific study of religions and religion and to support its expansion internationally. It was twice founded. The first time, informally, by a group of scientifically-oriented historians of religion under the leadership of Jean Réville who initiated a series of international "history of religions" congresses beginning with the Paris Exposition in 190o. This was done in deliberate opposition to scholars with a wider religious and moral vision for the study of religion, inspired by the 1893 World's Parliament of Religions held in Chicago. Its second founding occurred in Amsterdam in 1950, at the seventh international meeting since the Paris congress, this time formally, as the International Association for the Study of the History of Religions (IASHR) with the modulation of its name to the IAHR at the eighth international congress in Rome in 1955 . 
Almost immediately after its founding in 1900, scholars with a "wider vision" for the study of religions sought legitimation for their activities within the IAHR. As early as the third international congress held in Oxford in 1908, organizers recognized the need formally to exclude presentations on spiritual and theological matters by those who could not distinguish such preoccupations from the scientific study defined by the Paris historians of religion. The "Rules of the Congress" in Oxford, as listed in the Transactions of the Third International Congress for the History of Religions (1908) read as follows: "If any reader or speaker contravenes the fundamental rule of the Congress which excludes confessional and dogmatic discussions, the Chairman of the meeting shall promptly intervene" (Vol. 1, Rule IX, p. xix). Nevertheless, a "cryptotheological element in the study of religion" soon found its way into the IAHR under the rubric of "phenomenology," and within the decade the IAHR was very nearly overrun by the intrusion of high-minded ambitions and extra-scientific goals by its tenth international congress in Marburg in 1960. The reaction to this development was explosive. It resulted in a harsh standoff between then Secretary General C. Jouco Bleeker and a relatively young upstart scholar named R. J. Zwi Werblowsky. Bleeker supported the wider, phenomenological approach to the study of religion that would allow students of religion to take up what he considered their broader cultural obligations in addition to their scientific activities. Werblowsky, in response, produced a set of "basic minimum presuppositions" to be honoured by members of the IAHR that would exclude such extra-scientific cultural tasks. The crisis at Marburg was resolved when sixteen scholars at the congress signed the Werblowsky manifesto and Bleeker, under the advice of Professor Annemarie Schimmel, announced that he had not put forward his suggestion as a platform to be accepted by the IAHR. The consequence of this resolution was critical in preventing the IAHR from being co-opted by and subordinated to the "wider vision" of scholars more interested in having the Association open itself to social, moral, political, and even religious objectives rather than remaining committed to seeking scientific knowledge about religion and religions. This resolution, however, remained fragile. As Werblowsky had pointed out, there was little acquaintance in nonWestern scholarly circles with the scientific approach of Western scholarship in this field and the IAHR's adoption of a policy of globalization was, therefore, bound to create problems.

The history of the IAHR's commitment to global expansion shows that the IAHR has added an ever-increasing number of national member associations and societies without concern as to whether or not they understood and were committed to the IAHR's scientific ideals for the study of religion. 
It is not surprising, therefore, that complaints have increasingly been raised about religious, social, political, and cultural objectives intruding its international congresses. And the pursuit by recent executive committees of the IAHR for a global expansion for the IAHR without vetting potential organizations with respect to their scientific priorities has now mired it in the same problems Werblowsky and his colleagues faced in Marburg in 1960. The Delphi meeting, however, made it clear that the objectives of the current Executive Committee of the IAHR were not at all those affirmed and reaffirmed at previous congresses. Although the current Executive Committee wished to benefit from the IAHR's historical reputation as a scientific organization, its first priority was not that of upholding that scientific profile. It is committed, rather, to expanding the remit of the IAHR beyond its original epistemic objective, just as Bleeker wished to add a social and moral study of religion to the scientific objective of the Association. And what happened in Delphi was not the resolution of the "Marburg" problem but rather a subordination of the IA HR's historical epistemic commitment to the extra-scientific tasks.

The EC's decision, if adopted, spells the demise of the IAHR as an association uniquely committed to a scientific study of religion. The EC, however, has not been transparent about this. As became clear from the decisions reached in Delphi, the EC is attempting to hide the implications of its "Delphi solution" to the resurgence of the "Marburg problem" with a change of name of the Association to the International Association for the Study of Religion.

This commitment of the EC to an "inclusivist" future for the IAHR, which it concluded prior to the Delphi meeting, became clear to me on the basis of a thorough analysis of their documents which framed the Delphi discussion, my correspondence with officers of the IAHR concerning the agenda of the Delphi meeting, and by two days of discussions and debates. I provide a detailed account of these issues in a book titled The Fall of the IAHR from the Delphi Summit: A Tale of its 2019 Extended Executive Committee Meeting (Edwin Mellen Press, 2020). I will here simply provide the reader a contrast between the EC's conclusions and mine regarding the future of the IAHR.

The EC provided their summary report on the "Outcomes of the Extended Executive Committee Meeting on the Future of the IAHR" in the November 2019 IAHR e-Bulletin Supplement (pp. 6-8) with a promise for a more detailed report sometime in the future. Although the Supplement mentions three "proposals" that emerged from the EC's meeting in Delphi, the central issues dealt 
with are how the EC can extricate the IAHR from its current strict and exclusivist scientific framework but to do so without jeopardizing its presently highly valued scientific profile. To that end, the EC proposes to change the name of the Association to the "International Association for the Study of Religion" (IASR), thereby evading the strictures of a scientific historiography in its current name and by simultaneously laying claim to that scientific reputation by "tightening up [its] scientific profile." As I point out below, the second task proved more difficult than the EC had first envisioned since it required that it insert the word "scientific" into the IAHR's Constitution.

The proposal that the EC insert the word "scientific" into the Constitution, a proposal which I made and argued for on the final day of discussions, presented a dilemma to the EC because it would mitigate the effectiveness of the change of the Association's name to the IASR in order to make the Association into a more inclusive kind of academic enterprise from that of its historical mandate as scientific. It appears that the EC thought it possible to avoid the dilemma by considering placing the word "scientific" in some other text related to the IAHR web site than in the Constitution. The EC it appears, however, made no decision on this matter in Delphi. Rather, this problem found a different kind of solution a month later.

This dilemma was not the only problem the EC faced. The EC was well aware that the proposal for a change of name for the IAHR had been made in the past and that it had been rejected because previous executive committees and International IAHR Councils believed its generic and amorphous character would function as an open invitation for religious and theological scholars to participate in the IAHR congresses and the conferences the IAHR sponsors. But the current EC sees this "inclusivist" move of the IAHR beyond its current scientific objectives as a benefit for its expansionist agenda. Thus, the current EC sought (seeks) to mitigate that concern on the basis of specious argumentation that "the situation surrounding the IAHR has been changing more rapidly" since the IAHR last rejected that proposal and the "study of religion" will be a better umbrella term for the new international organization (IASR) because "many of the IAHR member societies and associations have adopted 'study of religion(s)' for their official names" (e-Bulletin Supplement, p. 6). However, the fact that many of the IAHR's member associations and societies use this generic and amorphous phrase in their names is not only irrelevant but misleading because those societies and associations have never been recognized as having had a scientific profile. Furthermore, the EC provides no argument or evidence to support its claim about alleged changes in the so-called "situation" surrounding the IAHR that could justify the claim made on behalf of the 
phrase "study of religion" in the context in which the IAHR finds itself today. Simply referring to what its national member associations do in this regard, moreover, flaunts followership rather than leadership by the EC.

It is worth noting here that the EC had already concluded that it would recommend a change of the name of the IAHR to the IASR sometime before the EEC meeting in Delphi. There is indication of this disappointing fact in the EC's "Summary of conclusions ..." where it is apparent they were fully aware that in changing the name they would have to mollify the defenders of Werblowsky's basic minimum presuppositions for the study of religion, but seem to have been caught off guard with my insistence that the word "scientific" be included in the Constitution. The relevant passage reads as follows: "As is indicated by way of the wording ... about the possible change of name, the $E C$, before the EEC and EC meetings in Delphi but also during its meeting in Delphi, was highly aware ... that a change of name was to be intimately linked to a tightening up of the academic, scientific profile of the IAHR/IASR. What was on the plate was not just a change of name but a change of name accompanied by a tightening up of the scientific profile" ("Summary of Conclusions ...," p. 6 emphasis added). Including the word "scientific" in the IAHR's Constitution, however, seems to have been considered by the EC simply as cover for the implications of their proposal for a change of name. This, it appears, accounts for the fact that the EC had not immediately agreed to my recommendation for its inclusion in the Constitution. However, in order not to give even the slightest ground unless forced, the Ec decided to qualify the use of "scientific" in the Constitution by pairing it with the word "Religionswissenschaft" on the presumption that the latter word has historically referred to a broader range of approaches to the study of religion than simply to its etymological meaning of scientific.

Those acquainted with the history of the IAH R - which should include everyone serving on the EC - are well aware of the Marburg crisis that was resolved by the IAHR committing itself to supporting a purely scientific study of religion. Everyone also knows that this has never satisfied all national member associations of the IAHR, and that IAHR practice, therefore, has often been at odds, with its ideals. However, until the Delphi meeting, no Ec has attempted to engineer an alteration in the epistemic commitment of the IAHR in such a surreptitious way. This EC has not had the courage to openly argue for an IAH R that can, like the American Academy of Religion or the European Academy of Religion, include moral, social, political, and cultural issues in its agendas and 
objectives. However, its insistence on changing the name of the IAHR to the generic and amorphous "International Association for the Study of Religions" (IASR) achieves the same ends. The openness and inclusiveness of the phrase "study of religion" will make it impossible to even delineate, let alone criticize, a discrepancy between the scientific ideals of the IAHR and the extra-scientific practices that would be welcomed by a new IASR.

This amounts to the demise of the IAHR as an association historically defined by its commitment to the ideal of a scientific study of religion.

\section{Acknowledgements}

I owe a profound debt of gratitude to Professor Luther H. Martin, my close friend, colleague, and sometime co-author for his enormous contribution to this essay and to the book-length version that provides argument and evidence that grounds my conclusions about the import of the Extended Executive Committee meeting held in Delphi. Despite having advised me that I would likely be disappointed with the results of that meeting, he engaged me in hours of discussion and debate about the future of the IAHR, gave critical attention to my arguments, and deftly edited my impassioned prose.

\section{References}

Ambasciano, Leonardo (2019). An Unnatural History of Religions: Academia, Post-Truth and the Quest for Scientific Knowledge. London: Bloomsbury Academic.

Ambasciano, Leonardo (2019). The Sisyphean discipline: A précis of An Unnatural History of Religions: Academia, Post-Truth and the Quest for Scientific Knowledge. Religio: Revue pro religionistiku (http:www.casr.cz/religonem.php).

Bleeker, C. Jouco (2016). Looking backward and forward. In: Tim Jensen and Armin Geertz, eds. Numen, The Academic Study of Religion, and the IAHR: Past, Present, and Prospects, pp. 21-28. Leiden: Brill.

Bleeker, C. Jouco (2016). The relation of the history of religions to kindred religious sciences, particularly theology, sociology of religion, psychology of religion and phenomenology of religion. In: Tim Jensen and Armin Geertz, eds. Numen, The Academic Study of Religion, and the IAHR: Past, Present, and Prospects, pp. 40-50. Leiden: Brill.

Bleeker, C. Jouco (2016). The future task of the history of religions. In: Tim Jensen and Armin Geertz, eds. Numen, The Academic Study of Religion, and the IAHR: Past, Present, and Prospects, pp. 67-8o. Leiden: Brill. 67-80. 
Brelich, Angelo (forthcoming). Some notes concerning a congress of the history of religions. In: Donald Wiebe, The Fall of the IAHR from the Delphi Summit: A Tale of its 2019 Extended Executive Committee Meeting. Lewiston, NY: Edwin Mellen Press. Originally published as "Ai margini del $10^{\circ}$ Congresso Internazionale di Storia delle Religioni (Marburgo, 11 e 17-9-196o)" in Studi e Materiali di Storia delle Religioni (SMSR) 31 (1960), pp. 121-128. Republished as "A proposito di un Congresso di Storia delle religioni" in Brelich, A. (1979). Storia delle religioni, perché?, ed. V. Lanternari, 130-136. Naples: Liguori. Translated into English by Leonardo Ambasciano.

Fujiwara, Satoko (2016). An analysis of sixty years of Numen: How much diversity have we achieved? In: Tim Jensen and Armin Geertz, eds. Numen, The Academic Study of Religion, and the IAHR: Past, Present, and Prospects, pp. 391-414. Leiden: Brill.

Jensen, Tim (2016). The EASR within (the world scenario of) the IAHR: Observations and reflections. In: Tim Jensen and Armin Geertz, eds. Numen, The Academic Study of Religion, and the IAHR: Past, Present, and Prospects, pp. 163-217. Leiden: Brill.

Jensen, Tim and Armin Geertz (2016). Numen, The Academic Study of Religion, and the IAHR: Past, Present, and Prospects. Leiden: Brill.

National Organizing Committee. (1961). Internationaler Kongress für Religionsgeschichte. Marburg: N. G. Elwert Verlag.

National Organizing Committee. (1993). Minutes of the Meeting of the International Committee of the IAHR held in Paris 19.9.1993 beginning at 14:15. The IAHR Bulletin 27, pp. 2-7. (with special reference the "Proposal concerning the name of the IAHR" 5-6).

Sharpe, Eric J. (2016). From Paris 1900 to Sydney 1985: An essay in retrospect and prospect. In: Tim Jensen and Armin Geertz, eds. Numen, The Academic Study of Religion, and the IAHR: Past, Present, and Prospects, pp. 99-11o. Leiden: Brill.

Schimmel, Annemarie (2016). Summary of the discussion. In: Tim Jensen and Armin Geertz, eds. Numen, The Academic Study of Religion, and the IAHR: Past, Present, and Prospects, pp. 81-85. Leiden: Brill.

Taves, Ann (2019). The future of the study of religion. An unpublished paper for the meeting of the Extended Executive Committee Meeting in Delphi, September 13-15, 2019 .

Werblowsky, R. J. Zwi (2016). Marburg-and after? In: Tim Jensen and Armin Geertz, eds. Numen, The Academic Study of Religion, and the IAHR: Past, Present, and Prospects, pp. 61-66. Leiden: Brill.

Wiebe, Donald (2016). Memory, text, and interpretation: A critical appreciation of IAHR International Congresses - 1975 to 2010. In: Tim Jensen and Armin Geertz, eds. Numen, The Academic Study of Religion, and the IAHR: Past, Present, and Prospects, pp. 253-282. Leiden: Brill. 